\title{
Effect of milk replacer program on digestion of nutrients in dairy calves
}

\author{
T. M. Hill, ${ }^{1}$ H. G. Bateman II, J. M. Aldrich, and R. L. Schlotterbeck \\ Akey, Nutrition and Research Center, PO Box 5002, Lewisburg, OH 45338
}

\begin{abstract}
There are concerns with feeding young dairy calves amounts of milk solids approaching $0.9 \mathrm{~kg}$ of dry matter (DM) or more because of slumps in average daily gain (ADG) at weaning and low starter intakes. Additionally, programs feeding more than $0.6 \mathrm{~kg}$ of DM have not been thoroughly tested for success at different weaning ages. Four milk replacer (MR) programs were compared in trial 1. Program A was $0.44 \mathrm{~kg}$ of DM of a $21 \%$ crude protein $(\mathrm{CP}), 21 \%$ fat $\mathrm{MR}$ powder fed daily for $42 \mathrm{~d}$. Program B was $0.66 \mathrm{~kg}$ of DM of a $27 \%$ CP, $17 \%$ fat MR powder fed daily for $42 \mathrm{~d}$. Program C was $0.66 \mathrm{~kg}$ of $\mathrm{DM}$ of a $27 \% \mathrm{CP}, 17 \%$ fat MR powder daily fed for $28 \mathrm{~d}$. Program D was up to $1.09 \mathrm{~kg}$ of DM of a $29 \%$ CP, $21 \%$ fat MR daily fed for $49 \mathrm{~d}$. Digestibility estimates were made and blood was sampled for serum constituents on d 53 to 56 , and performance was measured for $84 \mathrm{~d}$. Three programs feeding a $27 \% \mathrm{CP}$, $17 \%$ fat MR powder were compared in trial 2 over $56 \mathrm{~d}$. Calves on program A were fed $0.66 \mathrm{~kg}$ of DM powder daily and weaned at $28 \mathrm{~d}$. Calves on program $\mathrm{B}$ were fed $0.66 \mathrm{~kg}$ of DM powder daily and weaned at $42 \mathrm{~d}$. Calves on program $\mathrm{C}$ were fed up to $1.09 \mathrm{~kg}$ of DM powder daily and weaned at $42 \mathrm{~d}$. Digestibility estimates were made and blood was sampled for serum constituents $\mathrm{d}$ 21 to 24 , d 36 to 39 , and d 53 to 56 . In trial 1, calves fed program A had the least overall ADG. Calves fed program D had the greatest ADG from 0 to $56 \mathrm{~d}$, the least ADG from d 56 to 84, the least digestibility estimates, and the least concentrations of serum amylase. At $84 \mathrm{~d}$, there were no differences in body weights of calves fed programs B, C, and D. In trial 2, calves fed program A had the greatest starter intake and greatest concentrations of serum amylase. Calves fed program $\mathrm{C}$ had the least estimates of digestibility from d 53 to 56 and the least serum concentrations of amylase. Calves fed up to $1.09 \mathrm{~kg} / \mathrm{d}$ of 27 to $29 \% \mathrm{MR}$ powders and weaned at 42 or $49 \mathrm{~d}$ had lower starter intakes, concentrations of serum amylase, and digestion of starter postweaning compared with calves fed conventional $21 \%$ CP, $21 \%$
\end{abstract}

Received June 5, 2009

Accepted November 23, 2009.

${ }^{1}$ Corresponding author: mhill@akey.com fat MR powders fed at $0.44 \mathrm{~kg} / \mathrm{d}$. Calves fed $0.66 \mathrm{~kg} / \mathrm{d}$ of a $27 \% \mathrm{CP}, 17 \%$ fat $\mathrm{MR}$ powder and weaned at 28 or $42 \mathrm{~d}$ of age had no reductions in intake or digestion compared with calves fed conventional MR and gained as much total body weight from 0 to $84 \mathrm{~d}$ as calves stepped up to $1.09 \mathrm{~kg}$ of MR.

Key words: calf, milk replacer, digestion

\section{INTRODUCTION}

Interest in feeding dairy calves more than the conventional 3.8 L of liquid milk or milk replacer (MR) daily has increased since Diaz et al. (2001) reported rapid and efficient BW gains in calves fed large amounts of MR without feeding any dry starter. However, the success of some high MR feeding rate programs when starter is fed has been plagued by a weaning and postweaning slump in ADG (Bar-Peled et al., 1997; Jasper and Weary, 2002; Cowles et al., 2006). This reduced ADG has been because of reduced starter intake and feed efficiency (Strzetelski et al., 2001; Hill et al., 2006a,b), reduced rumen development and function (Terre et al., 2006), or reduced digestion of the starter (Terre et al., 2007). A $27 \% \mathrm{CP}, 17 \%$ fat MR powder fed at $0.66 \mathrm{~kg}$ of $\mathrm{DM} / \mathrm{d}$ has been successful at improving ADG and not reducing starter intake compared with a $21 \% \mathrm{CP}, 21 \%$ fat MR fed at $0.44 \mathrm{~kg}$ of DM/d (Hill et al., 2006b); however, this program does not maximize ADG during the first month of life, but does maximize ADG during the second and third months of life (Hill et al., 2007b).

Starter intake, and specifically that of starters high in starch concentration, serves to develop the rumen epithelium from the yield of volatile fatty acids from fermentation (Warner et al., 1956). Additionally, pancreatic amylase secretion increases with age and the amount of starch consumed (Guilloteau et al., 1985). Thus, feeding more milk or MR to enhance calf growth is counterproductive to development of the calf's rumen and pancreatic enzyme system needed to digest starter and other dry feeds postweaning.

One way to overcome the slump in ADG and starter intake at weaning time could be to implement a gradual weaning program as tested by Khan et al. (2007a, b). They slowly increased the milk offered until $23 \mathrm{~d}$ of age and slowly removed milk until $49 \mathrm{~d}$ of age. However, 
this gradual increase and decrease in milk or MR is not practical to implement on many farms.

Early weaning has been shown to not reduce ADG in calves when conventional milk and MR programs are employed (Owen and Larson, 1982; Kehoe et al., 2007). Early weaning does not appear to have been tested in calves fed more than $0.6 \mathrm{~kg}$ DM of milk or MR. Intuitively, early weaning may not work with high rates of MR fed because of the time needed to increase the rate of MR fed and then decrease it to wean without having the slump in ADG and starter intake. However, early weaning is a way to reduce the cost of a MR program through the reduction in the amount of expensive MR fed and reduction in the labor costs to manage the calf fed MR.

From the existing research, our first hypothesis was that if the amount of MR fed was too high, starter intake, digestion, and ADG would be reduced in young calves postweaning. Our second hypothesis was that early weaning would reduce ADG in calves fed at moderate amount of MR $(27 \%$ CP, $17 \%$ fat MR powder fed at $0.66 \mathrm{~kg}$ of $\mathrm{DM} / \mathrm{d}$ ). Our objectives were to evaluate these hypotheses using 2 digestion trials to test the feeding rate of MR and weaning age of calves.

\section{MATERIALS AND METHODS}

\section{General}

Holstein bull calves that were 2 to $4 \mathrm{~d}$ of age from a single dairy farm were received at midday after a $3.5-\mathrm{h}$ transit. For each trial, all calves arrived at one time. At the p.m. feeding, calves were randomly assigned to experimental programs. The day after arrival at approximately noon, the calves were weighed $(\mathrm{d} 0$, initial BW). At this time, blood was sampled intravenously, serum was separated by centrifugation at 3,000 $\times g$ (VWR, Batavia, IL), and serum protein concentration was estimated using an optical refractometer (Atago U.S.A. Inc., Bellevue, WA). General calf management, health protocols, and measurements of BW, starter intake, fecal scoring, body condition scoring, and nutrient analysis of feeds (all methods for feed analysis were from AOAC, 2000) were conducted as described in Hill et al. (2007a, 2008a). Chromium (AOAC, 2000; method 993.14) concentrations were determined in the feed and feces of calves and used to estimate digestibility of DM consumed. Serum was analyzed for albumin, alkaline phosphatase, amylase, creatinine, glucose, total protein, and urea-N. These serum constituents could be markers for protein status (albumin, total protein, urea-N), bone growth (alkaline phosphatase), enzyme development and digestion (amylase), muscle growth (creatinine), and energy status (glucose).
During both trials, calves were initially housed in a curtain-sided, naturally ventilated nursery with no added heat in 1.2- $\times 2.4-\mathrm{m}$ pens bedded with straw for the first $56 \mathrm{~d}$. For the next $28 \mathrm{~d}$ in trial 1, calves were housed in group pens $(6$ calves per pen, 2 pens pretreatment) with $5.5 \mathrm{~m}^{2}$ of outside pen space and 0.9 $\mathrm{m}^{2}$ of inside pen space per calf. Calves were initially assigned to group pens when received, and then randomly assigned to individual pens within the nursery, using group pen assignment as a blocking factor. The inside pen space was bedded with straw and there was no added heat. Calves had access to clean, fresh water and starter at all times. All animals were cared for as described in the Guide for the Care and Use of Agricultural Animals in Agricultural Research and Teaching (FASS, 1999). Calves in trial 2 were used only while individually housed.

Calves were weighed initially and every $7 \mathrm{~d}$ thereafter. Hip widths of the calves were measured with a caliper, and BCS was estimated initially and every $14 \mathrm{~d}$ thereafter. Calf BCS was based on a 1 to 5 system using 0.25-unit increments with 1 being emaciated and 5 being obese (Wildman et al., 1982). Scores were based on changes around the vertical and transverse processes of the spine as palpated by one experienced technician. Starter intake offered and refused was measured daily. Feces were scored daily in the first $56 \mathrm{~d}$ ( 1 to 5 scale; 1 = firm, normal, 2 = less firm, normal, $3=$ thick, batter-like, $4=$ thin, batter-like, $5=$ watery). Empty BW ADG was estimated by first estimating gut fill (fill as a percentage of $\mathrm{BW}=10.4-0.39 \operatorname{diet} \mathrm{CP} \%+0.41$ diet ADF \%) and correcting BW as described by Jahn and Chandler (1976).

To estimate the number of calves needed for the trials, power analyses for different measurements were conducted using the residual error mean squares and means from previous trials in our research unit. Using 20 similar trials, an $11 \%$ difference in ADG means could be separated at $P<0.05$ with 12 calves per treatment. Using 3 digestion trials, a $5 \%$ difference in DM digestibility could be separated at $P<0.05$ with 4 calves per treatment. Serum data from 10 trials predicted a $10 \%$ difference in serum urea nitrogen or amylase means could be separated at $P<0.05$ with 4 calves per treatment.

\section{Trial 1}

Four MR programs were compared using 12 calves/ program $(46 \pm 1.2 \mathrm{~kg}$ of BW). Program A was $0.44 \mathrm{~kg}$ DM of a $21 \%$ CP, $21 \%$ fat MR powder (Akey, Lewisburg, OH) fed daily for $42 \mathrm{~d}$. Program B was $0.66 \mathrm{~kg}$ DM of a $27 \%$ CP, $17 \%$ fat MR powder (Akey) fed daily 
Table 1. Analyzed nutrient composition of milk replacers, starters, growers, and hay used in the grower in trial 1

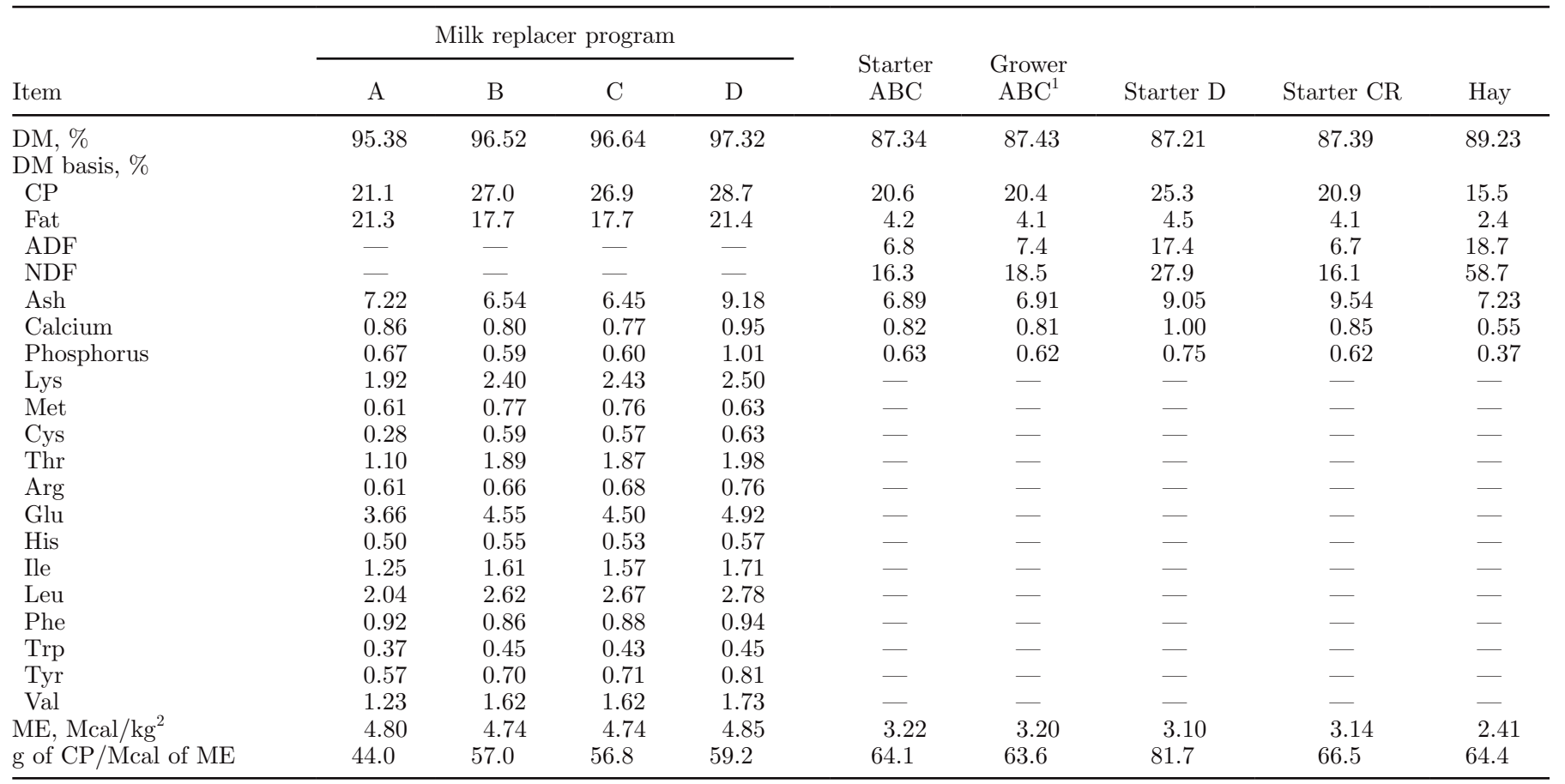

${ }^{1}$ Hay was $5 \%$ of grower ABC (as-fed basis).

${ }^{2}$ Calculated using NRC (2001) equations.

for $42 \mathrm{~d}$. Program C was $0.66 \mathrm{~kg} \mathrm{DM}$ of a $27 \% \mathrm{CP}, 17 \%$ fat MR powder (Akey) fed daily for $28 \mathrm{~d}$. Program D was up to $1.09 \mathrm{~kg}$ DM of a $29 \% \mathrm{CP}, 21 \%$ fat MR powder (Land O'Lakes Inc., Shoreview, MN) fed daily for $49 \mathrm{~d}$. All MR were reconstituted at the rate of $134 \mathrm{~g}$ of as-fed powder into a volume of $1 \mathrm{~L}$ with warm water $\left(45^{\circ} \mathrm{C}\right)$. To facilitate weaning of calves on programs $\mathrm{A}, \mathrm{B}$, and $\mathrm{C}$, the MR were only fed at the a.m. feeding of the last $3 \mathrm{~d}$ of the assigned MR feeding period. Calves on program D were fed $0.78 \mathrm{~kg}$ of $\mathrm{DM} / \mathrm{d}$ for d 0 to $7,1.09$ $\mathrm{kg}$ of $\mathrm{DM} / \mathrm{d}$ for d 8 to 42 , and $0.54 \mathrm{~kg}$ of $\mathrm{DM} / \mathrm{d}$ for $\mathrm{d} 43$ to 49. In each program, all calves consumed all of the MR offered. Calves on programs $\mathrm{A}, \mathrm{B}$, and $\mathrm{C}$ were fed a $20 \% \mathrm{CP}$ textured starter (starter ABC, Akey) from d 1 to 56 and a $20 \% \mathrm{CP}$ grower (grower $\mathrm{ABC}$, which contained $5 \%$ chopped hay; Akey) from d 56 to 84 . The hay was leafy grass hay (mostly timothy). Calves on program D were fed a $25 \% \mathrm{CP}$ textured starter (Land O'Lakes) from d 0 to 84 . From d 42 to 56, $43 \mathrm{~g}$ of DM/ calf daily of a $20 \%$ CP pelleted feed (starter CR; Akey) containing chromic oxide $(2.5 \%)$ was fed in addition to free-choice starter. Consumption was assured by first blending the $43 \mathrm{~g}$ with a portion of the assigned starter and allowing the calves to consume all of this feed allotment. Then, additional amounts of the assigned starter were offered ad libitum. The basis was to achieve an intake of chromic oxide per calf daily exceeding the minimum suggested $1 \mathrm{~g} /$ calf daily for digestibility estimates (Bouchard et al., 1973). Fecal grab samples were taken from 4 calves randomly selected per program d 52 to 56 , frozen daily, combined on an equal wet weight basis, and subsampled for analysis. Fecal samples were systematically collected such that a total of 12 fecal samples were collected over the $4 \mathrm{~d}$ to represent every $2 \mathrm{~h}$ in a 24 -h period. Measured concentrations of $\mathrm{Cr}$ and other nutrients in the feed, feed intake, and in the feces were used to estimate fecal output and apparent digestibility. Blood was sampled on d 56 from the same 4 calves per program that were used for feces collection, and serum obtained via centrifugation was analyzed as described previously. Analyzed nutrient content of the diets is shown in Table 1. The trial was conducted July through September; the average temperature was $23^{\circ} \mathrm{C}$, and ranged from 11 to $36^{\circ} \mathrm{C}$.

Data were analyzed as a completely randomized design using repeated measures over time by Proc Mixed in SAS (Version 8, SAS Institute Inc., Cary, NC). Treatment means were separated using Tukey's honestly significant difference comparisons if the overall $F$ test for the measurement was significant $(P<0.05)$. Because of differences in handling of calves, data were analyzed separately for d 0 to 56 and d 56 to 84 . During d 0 to 56 , the experimental unit was calf. During d 56 to 84 , the experimental unit was pen. 
Table 2. Analyzed nutrient composition of feeds in trial 2

\begin{tabular}{lcc}
\hline Item & Milk replacer & Starter \\
\hline DM, \% & 96.2 & 87.3 \\
DM basis, \% & 26.9 & 21.1 \\
CP & 18.0 & 4.0 \\
Fat & - & 6.9 \\
ADF & - & 16.7 \\
NDF & 6.78 & 7.10 \\
Ash & 0.84 & 0.88 \\
Calcium & 0.63 & 0.58 \\
Phosphorus & 4.74 & 3.22 \\
ME, Mcal/kg & & 65.5 \\
g of CP/Mcal of ME & 56.8 & \\
\hline
\end{tabular}

${ }^{1}$ Calculated using NRC (2001) equations.

\section{Trial 2}

Three MR programs were compared using 5 calves/ program $(43 \pm 1.5 \mathrm{~kg}$ of $\mathrm{BW})$. All calves were fed a $27 \% \mathrm{CP}, 17 \%$ fat MR powder (Akey) and a $20 \% \mathrm{CP}$ textured starter (Akey). Calves on program A were fed $0.66 \mathrm{~kg} \mathrm{DM}$ daily and weaned at $28 \mathrm{~d}$. Calves on program B were fed $0.66 \mathrm{~kg}$ DM daily and weaned at $42 \mathrm{~d}$. Calves on program B were fed up to $1.09 \mathrm{~kg}$ DM daily and weaned at $42 \mathrm{~d}$. The MR were reconstituted at the rate of $134 \mathrm{~g}$ of as-fed powder into a volume of $1 \mathrm{~L}$ with warm water $\left(45^{\circ} \mathrm{C}\right)$. To facilitate weaning of calves on programs $\mathrm{A}$ and $\mathrm{B}$, the $\mathrm{MR}$ were fed only at the a.m. feeding of the last $3 \mathrm{~d}$ of the assigned MR feeding period. Calves on program $\mathrm{C}$ were fed $0.78 \mathrm{~kg}$ of $\mathrm{DM} / \mathrm{d}$ for d 0 to $7,1.09 \mathrm{~kg}$ of $\mathrm{DM} / \mathrm{d}$ for d 8 to 35 , and $0.54 \mathrm{~kg}$ of $\mathrm{DM} / \mathrm{d}$ for d 36 to 42 . In each program, all calves consumed all of the MR offered. Both the MR and starter contained $0.25 \%$ chromic oxide as a digestibility marker. Fecal grab samples were collected during 3 periods of $4 \mathrm{~d}$ each (d 21 to 24 , d 36 to 39 , and $\mathrm{d} 53$ to 56) using the system described previously such that every $2 \mathrm{~h}$ of a 24 -h period were represented. Samples were handled and calculations were made as described in trial 1. Blood was sampled on d 21, 35, and 56 to correspond with the digestion measurements, and serum was analyzed as described previously. Analyzed nutrients of the diets are shown in Table 2. The trial was conducted from February through April. The average temperature was $4^{\circ} \mathrm{C}$ and ranged from -16 to $27^{\circ} \mathrm{C}$.

Growth data were analyzed as a completely randomized design using repeated measures over time by Proc Mixed in SAS. Intake, digestion, and serum metabolite data were analyzed by measurement period as a completely randomized design using a mixed model. When the overall $F$ test for the measurement was significant $(P<0.05)$, contrast statements of program A versus $\mathrm{B}$ and program $\mathrm{B}$ versus $\mathrm{C}$ were used to separate the means. The experimental unit was calf.

\section{RESULTS}

There were no differences in the initial measurements of serum protein concentrations, BW, and hip widths in either of the trials. Target nutrient concentrations of the various MR powders were achieved (Tables 1 and 2). All MR offered was consumed. No calves died or were removed from the trials.

\section{Trial 1}

Calves fed program $\mathrm{D}$ had the greatest $(P<0.05)$ ADG from 0 to $56 \mathrm{~d}$ and had the greatest $(P<0.05)$ BW at d 56, whereas calves fed program A had the least $(P<0.05)$ ADG from 0 to $56 \mathrm{~d}$ and the least $(P$ $<0.05$ ) BW at d 56 (Table 3). Empty BW ADG was the least $(P<0.05)$ for calves fed program $\mathrm{A}$ and not different among calves fed programs B, C, or D from 0 to $56 \mathrm{~d}$. Calves fed program $\mathrm{C}$ had the greatest $(P$ $<0.05)$ ADG and empty BW ADG from 56 to $84 \mathrm{~d}$. Calves fed programs $\mathrm{A}$ and $\mathrm{D}$ had the least $(P<0.05)$ ADG from 56 to $84 \mathrm{~d}$. Calf BW at d 84 was the least $(P<0.05)$ for calves fed program $\mathrm{A}$ and not different among calves fed programs B, C, or D. Starter intake was greatest $(P<0.05)$ for calves fed program $\mathrm{C}$ and least $(P<0.05)$ for calves fed program $\mathrm{D}$ from 0 to 56 d. Total intake (MR plus starter) was greatest $(P$ $<0.05)$ for calves fed program $\mathrm{D}$ and least $(P<0.05)$ for calves fed program A from 0 to $56 \mathrm{~d}$. Starter intake was greatest $(P<0.05)$ for calves fed program $\mathrm{C}$ from d 56 to 84. Feed efficiency and changes in BCS and hip widths were not different among programs. Average fecal score and abnormal fecal score days were greatest $(P<0.05)$ in calves fed program D.

The fractional digestibility of DM and OM was less $(P<0.05)$ in calves fed program D (Table 4$)$. Calves fed program $\mathrm{D}$ also had the least $(P<0.05)$ amount of OM digested. Calves fed program $\mathrm{D}$ digested less $(P<$ 0.05) DM than calves fed program B and C, whereas digestion of $\mathrm{OM}$ in calves fed program A was intermediate $(P<0.05)$ and not different from the other programs.

Serum amylase concentrations were the least $(P<$ 0.05 ), whereas serum urea $\mathrm{N}$ concentrations were the greatest $(P<0.05)$ for calves fed program D (Table $5)$. Serum concentrations of albumin, alkaline phosphatase, amylase, and total protein did not differ among groups.

\section{Trial 2}

In trial 2, performance measurements did not differ among calves fed the $3 \mathrm{MR}$ programs (Table 6); however, this is not surprising considering there were 
only 5 calves per program. Trial 2 was not designed to evaluate differences in growth of calves fed the different programs. Rather, it was designed to evaluate differences in digestibility of diets and selected plasma metabolites of calves fed different MR programs. In the first measurement period, there were no differences between calves fed programs A and B (Table 7). Intakes were greater $(P<0.05)$ in calves fed program $\mathrm{C}$ versus program $\mathrm{B}$. The digestibility of $\mathrm{Ca}$ in calves fed program $\mathrm{C}$ was less $(P<0.05)$ than that in calves fed program $\mathrm{B}$. The amount of $\mathrm{DM}, \mathrm{OM}, \mathrm{CP}$, fat, and $\mathrm{P}$ digested in calves fed program $\mathrm{C}$ was greater $(P<0.05)$ than that in calves fed program B.
In the second measurement period, intake of starter $\mathrm{DM}$, total DM and OM, and $\mathrm{P}$ was greatest in calves fed program $\mathrm{A}$, least in calves fed program $\mathrm{C}$, and intermediate in calves fed program $\mathrm{B}(P<0.05$; Table $8)$. Intake of fat differed and ranked greatest in calves fed program B, intermediate in calves fed program $\mathrm{C}$, and least in calves fed program A $(P<0.05)$. Intake of $\mathrm{CP}$ was greater $(P<0.05)$ in calves fed program $\mathrm{B}$ versus program $\mathrm{C}$. Intake of Ca was greater $(P<0.05)$ in calves fed program A versus program B. Digestibility fraction of $\mathrm{DM}, \mathrm{OM}$, fat, $\mathrm{Ca}$, and $\mathrm{P}$ were different and ranked greatest in calves fed program $\mathrm{B}$, intermediate in calves fed program $\mathrm{A}$, and least in calves fed

Table 3. Performance of calves fed different milk replacer (MR) and starter programs in trial 1

\begin{tabular}{|c|c|c|c|c|c|c|}
\hline \multirow[b]{2}{*}{ Item } & \multicolumn{4}{|c|}{ Milk replacer program } & \multirow[b]{2}{*}{ SEM } & \multirow[b]{2}{*}{$P>\mathrm{F}$} \\
\hline & $\mathrm{A}$ & B & $\mathrm{C}$ & $\mathrm{D}$ & & \\
\hline MR CP, \% & 21.1 & 27.0 & 26.9 & 28.7 & & \\
\hline MR fat, $\%$ & 21.3 & 17.7 & 17.7 & 21.4 & & \\
\hline Days fed MR, $\mathrm{n}$ & 42 & 42 & 28 & 49 & & \\
\hline Maximum MR fed daily, $\mathrm{kg}$ & 0.44 & 0.66 & 0.66 & 1.09 & & \\
\hline Total MR intake, kg/calf & 17.5 & 26.6 & 17.4 & 48.1 & & \\
\hline Initial BW, kg & 45.4 & 45.3 & 46.3 & 45.7 & 1.19 & 0.18 \\
\hline $56-\mathrm{d}$ BW, kg & $72.1^{\mathrm{a}}$ & $79.1^{\mathrm{b}}$ & $78.6^{\mathrm{b}}$ & $82.2^{\mathrm{c}}$ & 1.62 & 0.04 \\
\hline Final 84-d BW, kg & $100.1^{\mathrm{a}}$ & $108.8^{\mathrm{b}}$ & $112.2^{\mathrm{b}}$ & $108.7^{\mathrm{b}}$ & 2.85 & 0.04 \\
\hline Initial serum protein, $\mathrm{mg} / \mathrm{dL}$ & 5.6 & 5.3 & 5.2 & 5.5 & 0.23 & 0.60 \\
\hline \multicolumn{7}{|l|}{$\mathrm{ADG}, \mathrm{kg} / \mathrm{d}$} \\
\hline $0-56 \mathrm{~d}$ & $0.48^{\mathrm{a}}$ & $0.60^{\mathrm{bc}}$ & $0.58^{\mathrm{b}}$ & $0.65^{\mathrm{c}}$ & 0.039 & 0.02 \\
\hline $56-84 \mathrm{~d}$ & $1.00^{\mathrm{a}}$ & $1.06^{\mathrm{b}}$ & $1.20^{\mathrm{c}}$ & $0.95^{\mathrm{a}}$ & 0.031 & 0.02 \\
\hline $0-84 \mathrm{~d}$ & 0.65 & 0.76 & 0.78 & 0.75 & - & - \\
\hline \multicolumn{7}{|l|}{ Empty BW ADG, ${ }^{1} \mathrm{~kg} / \mathrm{d}$} \\
\hline $0-56 \mathrm{~d}$ & $0.43^{\mathrm{a}}$ & $0.55^{\mathrm{b}}$ & $0.52^{\mathrm{b}}$ & $0.56^{\mathrm{b}}$ & 0.036 & 0.02 \\
\hline $56-84 \mathrm{~d}$ & $0.94^{\mathrm{ab}}$ & $1.00^{\mathrm{b}}$ & $1.13^{\mathrm{c}}$ & $0.87^{\mathrm{a}}$ & 0.029 & 0.02 \\
\hline $0-84 \mathrm{~d}$ & 0.60 & 0.70 & 0.72 & 0.66 & - & - \\
\hline \multicolumn{7}{|l|}{ Starter intake, $\mathrm{kg} / \mathrm{d}$} \\
\hline $0-56 \mathrm{~d}$ & $0.724^{\mathrm{a}}$ & $0.728^{\mathrm{a}}$ & $0.908^{\mathrm{b}}$ & $0.667^{\mathrm{c}}$ & 0.0466 & 0.01 \\
\hline $56-84 \mathrm{~d}$ & $2.583^{\mathrm{a}}$ & $2.716^{\mathrm{a}}$ & $3.173^{\mathrm{b}}$ & $2.828^{\mathrm{a}}$ & 0.1864 & 0.03 \\
\hline \multicolumn{7}{|l|}{ Total intake, $\mathrm{kg} / \mathrm{d}$} \\
\hline $0-56 \mathrm{~d}$ & $1.037^{\mathrm{a}}$ & $1.204^{\mathrm{b}}$ & $1.220^{\mathrm{b}}$ & $1.525^{\mathrm{c}}$ & 0.0819 & 0.02 \\
\hline $56-84 \mathrm{~d}$ & $2.583^{\mathrm{a}}$ & $2.716^{\mathrm{a}}$ & $3.173^{\mathrm{b}}$ & $2.828^{\mathrm{a}}$ & 0.1923 & 0.03 \\
\hline \multicolumn{7}{|l|}{ Feed efficiency $^{2}$} \\
\hline $0-56 \mathrm{~d}$ & 0.460 & 0.501 & 0.472 & 0.428 & 0.0252 & 0.36 \\
\hline $56-84 \mathrm{~d}$ & 0.387 & 0.391 & 0.379 & 0.334 & 0.0193 & 0.08 \\
\hline \multicolumn{7}{|l|}{ Average fecal score $^{3}$} \\
\hline $0-56 \mathrm{~d}$ & $1.8^{\mathrm{a}}$ & $1.8^{\mathrm{a}}$ & $1.9^{\mathrm{a}}$ & $2.1^{\mathrm{b}}$ & 0.17 & 0.03 \\
\hline \multicolumn{7}{|l|}{ Abnormal fecal score days ${ }^{3}$} \\
\hline $0-56 \mathrm{~d}$ & $0.3^{\mathrm{a}}$ & $0.4^{\mathrm{a}}$ & $0.5^{\mathrm{a}}$ & $0.9^{\mathrm{b}}$ & 0.07 & 0.01 \\
\hline \multicolumn{7}{|l|}{$\mathrm{BCS}^{4}$} \\
\hline Initial & 2.3 & 2.3 & 2.3 & 2.3 & 0.04 & 0.67 \\
\hline $0-56 \mathrm{~d}$ change & 0.3 & 0.4 & 0.3 & 0.4 & 0.06 & 0.53 \\
\hline 56-84 d change & 0.2 & 0.1 & 0.2 & 0.1 & 0.01 & 0.09 \\
\hline \multicolumn{7}{|l|}{ Hip width, cm } \\
\hline Initial & 17.7 & 18.1 & 18.2 & 18.4 & 0.25 & 0.25 \\
\hline $0-56 \mathrm{~d}$ change & 2.8 & 3.1 & 3.0 & 3.4 & 0.26 & 0.36 \\
\hline $56-84$ d change & 3.2 & 3.3 & 3.1 & 3.0 & 0.31 & 0.62 \\
\hline
\end{tabular}

${ }^{\mathrm{a}-\mathrm{c}}$ Within a row, means with different superscripts differ $(P<0.05)$.

${ }^{1}$ Empty BW ADG was estimated by first estimating gut fill (fill as a percentage of BW $=10.4-0.39$ diet CP $\%+0.41$ diet ADF \%) and correcting BW as described by Jahn and Chandler (1976).

${ }^{2} \mathrm{BW}$ gain divided by milk replacer plus starter intake.

${ }^{3} 1$ to 5 system: 1 = firm, normal, $2=$ less firm, normal, $3=$ thick, batter-like, $4=$ thin, batter-like, $5=$ watery; abnormal $>2$.

${ }^{4} 1$ to 5 system: $1=$ thin, $5=$ fat. 
Table 4. Postweaning digestibility of starter from calves fed different milk replacer (MR) and starter programs (measured during d 53 to 56) in trial 1

\begin{tabular}{|c|c|c|c|c|c|c|}
\hline \multirow[b]{2}{*}{ Item } & \multicolumn{4}{|c|}{ Milk replacer program } & \multirow[b]{2}{*}{ SEM } & \multirow[b]{2}{*}{$P>\mathrm{F}$} \\
\hline & $\mathrm{A}$ & B & $\mathrm{C}$ & $\mathrm{D}$ & & \\
\hline MR CP, \% & 21.1 & 27.0 & 26.9 & 28.7 & & \\
\hline MR fat, $\%$ & 21.3 & 17.7 & 17.7 & 21.4 & & \\
\hline Days fed MR, n & 42 & 42 & 28 & 49 & & \\
\hline Maximum MR fed daily, $\mathrm{kg}$ & 0.44 & 0.66 & 0.66 & 1.09 & & \\
\hline \multicolumn{7}{|l|}{ Intake, $\mathrm{g} / \mathrm{d}$} \\
\hline As-fed & 2,206 & 2,349 & 2,539 & 1,903 & 221.8 & 0.08 \\
\hline DM & 1,926 & 2,052 & 2,218 & 1,659 & 194.3 & 0.08 \\
\hline $\mathrm{OM}$ & 1,811 & 1,928 & 2,084 & 1,528 & 182.0 & 0.06 \\
\hline $\mathrm{CP}$ & 351 & 374 & 404 & 366 & 36.4 & 0.54 \\
\hline Fat & 71 & 75 & 81 & 65 & 6.7 & 0.18 \\
\hline \multicolumn{7}{|l|}{ Digestibility, $\mathrm{g} / \mathrm{g}$ of intake } \\
\hline DM & $0.756^{\mathrm{a}}$ & $0.783^{\mathrm{a}}$ & $0.787^{\mathrm{a}}$ & $0.673^{\mathrm{b}}$ & 0.0219 & 0.01 \\
\hline $\mathrm{OM}$ & $0.774^{\mathrm{a}}$ & $0.783^{\mathrm{a}}$ & $0.787^{\mathrm{a}}$ & $0.680^{\mathrm{b}}$ & 0.0220 & 0.01 \\
\hline $\mathrm{CP}$ & 0.724 & 0.723 & 0.741 & 0.718 & 0.0258 & 0.83 \\
\hline Fat & 0.703 & 0.754 & 0.763 & 0.754 & 0.0337 & 0.33 \\
\hline \multicolumn{7}{|l|}{ Digested, g/d } \\
\hline $\mathrm{DM}$ & $1,452^{\mathrm{ab}}$ & $1,573^{\mathrm{a}}$ & $1,707^{\mathrm{a}}$ & $1,119^{\mathrm{b}}$ & 154.1 & 0.02 \\
\hline $\mathrm{OM}$ & $1,398^{\mathrm{a}}$ & $1,511^{\mathrm{a}}$ & $1,641^{\mathrm{a}}$ & $1,041^{\mathrm{b}}$ & 146.2 & 0.01 \\
\hline $\mathrm{CP}$ & 251 & 271 & 299 & 264 & 24.6 & 0.30 \\
\hline Fat & 49 & 57 & 62 & 49 & 5.7 & 0.14 \\
\hline
\end{tabular}

${ }^{\mathrm{a}, \mathrm{b}}$ Within a row, means with different superscripts differ $(P<0.05)$.

program $\mathrm{C}(P<0.05)$. The amount of $\mathrm{DM}$ and $\mathrm{OM}$ digested differed and ranked greatest in calves fed program A, intermediate in calves fed program $\mathrm{B}$, and least in calves fed program $\mathrm{C}(P<0.05)$. The amount of fat digested differed and ranked greatest in calves fed program $\mathrm{B}$, intermediate in calves fed program $\mathrm{C}$, and least in calves fed program A $(P<0.05)$. The amounts of $\mathrm{CP}, \mathrm{Ca}$, and $\mathrm{P}$ digested were greater $(P<0.05)$ in calves fed program A versus B.

During the third measurement period, intakes of all nutrients differed and were greatest in calves fed program $\mathrm{A}$, intermediate in calves fed program $\mathrm{B}$, and least in calves fed program $\mathrm{C}(P<0.05$; Table 9$)$. Calves fed program $\mathrm{C}$ had lower $(P<0.05)$ digestibility of $\mathrm{DM}$,
$\mathrm{OM}, \mathrm{Ca}$, and $\mathrm{P}$ than calves fed program $\mathrm{B}$. The amount of $\mathrm{DM}, \mathrm{OM}, \mathrm{CP}$, and fat digested differed and ranked greatest in calves fed program A, intermediate in calves fed program $\mathrm{B}$, and least in calves fed program $\mathrm{C}(P$ $<0.05)$.

Serum amylase concentrations were lower $(P<0.05)$ for calves fed program $\mathrm{C}$ than program $\mathrm{B}$ on d 21, 35, and 56 (Table 10). On d 56, serum amylase concentration was lower $(P<0.05)$ for calves fed program B than for calves fed program A. Serum urea N concentrations were greater $(P<0.05)$ in calves fed program C compared with B on d 21. Serum concentrations of albumin, alkaline phosphatase, and total protein did not differ.

Table 5. Postweaning serum constituents from calves fed different milk replacer (MR) and starter programs (measured d 56) in trial 1

\begin{tabular}{|c|c|c|c|c|c|c|}
\hline \multirow[b]{2}{*}{ Item } & \multicolumn{4}{|c|}{ Milk replacer program } & \multirow[b]{2}{*}{ SEM } & \multirow[b]{2}{*}{$P>\mathrm{F}$} \\
\hline & $\mathrm{A}$ & B & $\mathrm{C}$ & $\mathrm{D}$ & & \\
\hline MR CP, \% & 21.1 & 27.0 & 26.9 & 28.7 & & \\
\hline MR fat, $\%$ & 21.3 & 17.7 & 17.7 & 21.4 & & \\
\hline Days fed MR, $\mathrm{n}$ & 42 & 42 & 28 & 49 & & \\
\hline Maximum MR fed daily, $\mathrm{kg}$ & 0.44 & 0.66 & 0.66 & 1.09 & & \\
\hline Alkaline phosphatase, units/L & 159 & 185 & 187 & 162 & 14.5 & 0.12 \\
\hline Amylase, units/L & $46.0^{\mathrm{a}}$ & $48.8^{\mathrm{a}}$ & $50.9^{\mathrm{a}}$ & $35.9^{\mathrm{b}}$ & 3.15 & 0.02 \\
\hline Total protein, $\mathrm{g} / \mathrm{L}$ & 59.2 & 60.1 & 59.5 & 59.8 & 3.34 & 0.34 \\
\hline Albumin, g/L & 18.6 & 18.4 & 18.8 & 18.5 & 0.77 & 0.45 \\
\hline Urea nitrogen, mmol/L & $3.6^{\mathrm{a}}$ & $3.5^{\mathrm{a}}$ & $3.5^{\mathrm{a}}$ & $4.6^{\mathrm{b}}$ & 0.47 & 0.04 \\
\hline Creatinine, $\mu \mathrm{mol} / \mathrm{L}$ & 76.8 & 90.6 & 84 & 75.4 & 6.83 & 0.12 \\
\hline Glucose, $\mathrm{mmol} / \mathrm{L}$ & 5.34 & 5.40 & 5.21 & 5.41 & 0.288 & 0.89 \\
\hline
\end{tabular}

${ }^{a, b}$ Within a row, means with different superscripts differ $(P<0.05)$. 
Table 6. Performance of 15 calves fed $27 \%$ CP, $17 \%$ fat milk replacer (MR) at different rates and weaned on different days (DM basis) in trial 2

\begin{tabular}{|c|c|c|c|c|}
\hline Item & $\begin{array}{c}\text { Program A: } 28-\mathrm{d} \\
\text { wean, } 0.66 \mathrm{~kg} / \mathrm{d}\end{array}$ & $\begin{array}{l}\text { Program B: } 42-\mathrm{d} \\
\text { wean, } 0.66 \mathrm{~kg} / \mathrm{d}\end{array}$ & $\begin{array}{l}\text { Program C: } 42-\mathrm{d} \\
\text { wean, } 1.09 \mathrm{~kg} / \mathrm{d}\end{array}$ & SEM \\
\hline Total MR fed, kg & 17.4 & 26.5 & 39.9 & - \\
\hline Initial serum protein, $\mathrm{mg} / \mathrm{dL}$ & 5.2 & 5.1 & 5.4 & 0.73 \\
\hline Initial BW, kg & 42.4 & 43.0 & 43.1 & 1.54 \\
\hline 56-d BW, kg & 72.4 & 74.2 & 79.2 & 4.09 \\
\hline $\mathrm{ADG}, \mathrm{kg} / \mathrm{d}$ & 0.54 & 0.56 & 0.64 & 0.062 \\
\hline Empty BW ADG,${ }^{1} \mathrm{~kg} / \mathrm{d}$ & 0.49 & 0.51 & 0.59 & 0.058 \\
\hline Starter DM intake, $\mathrm{kg} / \mathrm{d}$ & 0.829 & 0.705 & 0.603 & 0.0760 \\
\hline Total DM intake, kg/d & 1.139 & 1.179 & 1.316 & 0.1287 \\
\hline Feed efficiency ${ }^{2}$ & 0.471 & 0.472 & 0.489 & 0.0488 \\
\hline Average fecal score ${ }^{3}$ & 2.1 & 2.1 & 2.1 & 0.24 \\
\hline Abnormal fecal score days ${ }^{3}$ & 0.6 & 0.6 & 0.8 & 0.08 \\
\hline \multicolumn{5}{|l|}{$\mathrm{BCS}^{4}$} \\
\hline Initial & 2.3 & 2.3 & 2.4 & 0.22 \\
\hline 0 to $56 \mathrm{~d}$ change & 0.3 & 0.3 & 0.4 & 0.04 \\
\hline \multicolumn{5}{|l|}{ Hip width, cm } \\
\hline Initial & 17.4 & 17.5 & 17.4 & 1.70 \\
\hline 0 to $56 \mathrm{~d}$ change & 2.9 & 3.0 & 3.1 & 0.28 \\
\hline
\end{tabular}

${ }^{1}$ Empty BW ADG was estimated by first estimating gut fill (fill as a percentage of BW $=10.4-0.39$ diet $\mathrm{CP}$ $\%+0.41$ diet ADF \%) and correcting BW as described by Jahn and Chandler (1976).

${ }^{2} \mathrm{BW}$ gain divided by MR plus starter intake.

${ }^{3} 1$ to 5 system: $1=$ firm, normal, $2=$ less firm, normal, $3=$ thick, batter-like, $4=$ thin, batter-like, $5=$ watery; abnormal $>2$.

${ }^{4} 1$ to 5 system: $1=$ thin, $5=$ fat.

\section{DISCUSSION}

The overall low growth rates in calves fed program A in trial 1 were expected because calves fed the other programs were provided with a greater amount of nutrients from MR during the early periods of their life.
Although calves fed program D were the heaviest and had the greatest ADG from 0 to $56 \mathrm{~d}$, their empty BW ADG from 0 to $56 \mathrm{~d}$ was not different from that of calves fed programs B and C. This lack of difference in empty BW ADG can be attributed to the greater fiber content of the starter fed with program D (Jahn

Table 7. Intake and apparent total-tract digestibility of nutrients in calves fed $27 \% \mathrm{CP}, 17 \%$ fat milk replacers (MR) at different rates and weaned on different days as determined on d 21 to 24 (DM basis) in trial 2

\begin{tabular}{|c|c|c|c|c|}
\hline Item & $\begin{array}{l}\text { Program A: } 28-d \\
\text { wean, } 0.66 \mathrm{~kg} / \mathrm{d}\end{array}$ & $\begin{array}{l}\text { Program B: } 42-\mathrm{d} \\
\text { wean, } 0.66 \mathrm{~kg} / \mathrm{d}\end{array}$ & $\begin{array}{l}\text { Program C: } 42-\mathrm{d} \\
\text { wean, } 1.09 \mathrm{~kg} / \mathrm{d}\end{array}$ & SEM \\
\hline \multicolumn{5}{|l|}{ Intake, $\mathrm{g} / \mathrm{d}$} \\
\hline Starter $\mathrm{DM}^{1}$ & 286 & 270 & 146 & 28.4 \\
\hline MR DM & 659 & 659 & 1,099 & - \\
\hline Total DM ${ }^{1}$ & 945 & 929 & 1,245 & 28.3 \\
\hline $\mathrm{OM}^{1}$ & 878 & 864 & 1,160 & 25.1 \\
\hline $\mathrm{CP}^{1}$ & 222 & 219 & 304 & 18.6 \\
\hline Fat $^{1}$ & 115 & 115 & 179 & 10.8 \\
\hline Calcium ${ }^{1}$ & 6.7 & 6.5 & 8.3 & 0.62 \\
\hline Phosphorus $^{1}$ & 4.8 & 4.7 & 6.3 & 0.56 \\
\hline \multicolumn{5}{|c|}{ Digestibility, $\mathrm{g} / \mathrm{g}$ of intake } \\
\hline DM & 0.866 & 0.855 & 0.859 & 0.0379 \\
\hline $\mathrm{OM}$ & 0.874 & 0.869 & 0.876 & 0.0374 \\
\hline $\mathrm{CP}$ & 0.770 & 0.767 & 0.758 & 0.0382 \\
\hline Fat & 0.907 & 0.890 & 0.908 & 0.0411 \\
\hline Calcium $^{1}$ & 0.701 & 0.699 & 0.571 & 0.0428 \\
\hline Phosphorus & 0.815 & 0.786 & 0.758 & 0.0383 \\
\hline \multicolumn{5}{|l|}{ Digested, g/d } \\
\hline $\mathrm{DM}^{1}$ & 818 & 794 & 1,069 & 60.4 \\
\hline $\mathrm{OM}^{1}$ & 767 & 750 & 1,017 & 58.6 \\
\hline $\mathrm{CP}^{1}$ & 171 & 168 & 231 & 28.9 \\
\hline Fat $^{1}$ & 105 & 102 & 163 & 25.0 \\
\hline Calcium & 4.7 & 4.6 & 4.7 & 0.42 \\
\hline Phosphorus $^{1}$ & 3.9 & 3.7 & 4.7 & 0.40 \\
\hline
\end{tabular}

${ }^{1}$ Programs B vs. C were different $(P<0.05)$ based on contrast statement. 
Table 8. Intake and apparent total-tract digestibility of nutrients in calves fed $27 \% \mathrm{CP}, 17 \%$ fat milk replacers (MR) at different rates and weaned on different days as determined on d 36 to 39 (DM basis) in trial 2

\begin{tabular}{|c|c|c|c|c|}
\hline Item & $\begin{array}{l}\text { Program A: } 28-d \\
\text { wean, } 0.66 \mathrm{~kg} / \mathrm{d}\end{array}$ & $\begin{array}{l}\text { Program B: 42-d } \\
\text { wean, } 0.66 \mathrm{~kg} / \mathrm{d}\end{array}$ & $\begin{array}{l}\text { Program C: 42-d } \\
\text { wean, } 1.09 \mathrm{~kg} / \mathrm{d}\end{array}$ & SEM \\
\hline \multicolumn{5}{|l|}{ Intake, $\mathrm{g} / \mathrm{d}$} \\
\hline Starter $\mathrm{DM}^{1,2}$ & 1,372 & 470 & 351 & 54.3 \\
\hline MR DM & - & 659 & 549 & - \\
\hline Total $\mathrm{DM}^{1,2}$ & 1,372 & 1,129 & 901 & 54.9 \\
\hline $\mathrm{OM}^{1,2}$ & 1,261 & 1,047 & 836 & 50.1 \\
\hline $\mathrm{CP}^{2}$ & 276 & 259 & 208 & 10.3 \\
\hline Fat $^{1,2}$ & 53 & 122 & 100 & 8.8 \\
\hline Calcium $^{1}$ & 11.9 & 8.3 & 6.5 & 0.61 \\
\hline Phosphorus ${ }^{1,2}$ & 7.4 & 5.8 & 4.6 & 0.53 \\
\hline \multicolumn{5}{|c|}{ Digestibility, $\mathrm{g} / \mathrm{g}$ of intake } \\
\hline $\mathrm{DM}^{1,2}$ & 0.801 & 0.866 & 0.758 & 0.0288 \\
\hline $\mathrm{OM}^{1,2}$ & 0.808 & 0.879 & 0.777 & 0.0289 \\
\hline $\mathrm{CP}$ & 0.782 & 0.806 & 0.763 & 0.0344 \\
\hline Fat $^{1,2}$ & 0.868 & 0.943 & 0.790 & 0.0351 \\
\hline Calcium $^{1,2}$ & 0.549 & 0.671 & 0.514 & 0.0508 \\
\hline Phosphorus ${ }^{1,2}$ & 0.691 & 0.822 & 0.565 & 0.0601 \\
\hline \multicolumn{5}{|l|}{ Digested, g/d } \\
\hline $\mathrm{DM}^{1,2}$ & 1,097 & 979 & 683 & 48.3 \\
\hline $\mathrm{OM}^{1,2}$ & 1,016 & 921 & 649 & 46.7 \\
\hline $\mathrm{CP}^{2}$ & 215 & 209 & 159 & 15.8 \\
\hline Fat $^{1,2}$ & 46 & 115 & 79 & 11.9 \\
\hline Calcium $^{2}$ & 6.5 & 5.5 & 3.4 & 0.56 \\
\hline Phosphorus $^{2}$ & 5.1 & 4.8 & 2.6 & 0.55 \\
\hline
\end{tabular}

${ }^{1}$ Programs A vs. B were different $(P<0.05)$ based on contrast statement.

${ }^{2}$ Programs B vs. $\mathrm{C}$ were different $(P<0.05)$ based on contrast statement.

and Chandler, 1976). The ADG of calves fed program D from d 56 to 84 was low because of reduced starter intake and reduced diet digestibility. The pattern of ADG of calves fed program D is consistent with that in previously cited research (Bar-Peled et al., 1997; Jasper and Weary, 2002; Cowles et al., 2006). The low starter intake of calves fed program D is also consistent with previously cited research (Strzetelski et al., 2001; Hill et al., 2006a, 2007b), as is the low dietary digestibility that may result in reduced rumen development and microbial function (Terre et al., 2006, 2007). High MR intakes appear to be substituting for starter at early ages, probably reducing rumen development and reducing pancreatic amylase to contribute to the slumps in ADG at and after weaning observed in the current and previous trials. The high MR feeding rate programs in each trial (D in trial 1 and $\mathrm{C}$ in trial 2) reduced the digestion of starter postweaning, similar to reports by Terre et al. (2007). Weaning early in trial 2 (program A) resulted in reduced digestion at d 36 to 39 when the diet changed from a highly digestible milk-based diet to a grain-based diet. This disadvantage of weaning was overcome, as shown by greater ADG from 56 to $84 \mathrm{~d}$ in calves fed the early-wean program $\mathrm{C}$ in trial 1.

The digestibility measurements during the last period of d 53 to 56 in trials 1 and 2 and those measured by Terre et al. (2007) were of similar magnitude. Terre et al. (2007) reported an OM digestibility of $78.7 \%$ in calves fed their low amount of MR and $71.8 \%$ in calves fed their high amount of MR. We observed a 6- to 9-percentage-unit reduction in postweaning $\mathrm{OM}$ digestibility as feeding rate of MR increased. Terre et al. (2006) used purine excretion to assess microbial and rumen development; purine excretion in calves fed high amounts of MR was $60 \%$ that of calves fed the low amount of MR presumably associated with reduced digestibility. We did not estimate rumen development in these trials, but we did note reductions in serum enzymes typically associated with digestion of dry feeds when the feeding rate of MR increased.

Several commercial programs that promote high feeding rates of high protein MR instruct feeders to wean calves slowly over a 7-d period by feeding half of the MR in a morning-only feeding regimen as implemented in program $\mathrm{D}$ in trial 1 and program $\mathrm{C}$ in trial 2, rather than using a more abrupt weaning program of $3 \mathrm{~d}$ as in the other programs in trials 1 and 2 . Khan et al. (2007a, b) tested a much longer duration of reduced milk feeding in an effort to overcome the slump in performance noted by so many researchers. Their results were promising to overcome the slump in growth but are complicated to practically implement on-farm. The weaning regimen used with calves fed the high rate of high-protein MR in the present trials did not appear to be long enough to prevent postweaning slumps in growth.

Several serum constituents are sometimes used as markers of lean body mass (creatinine, albumin), 
Table 9. Intake and apparent total-tract digestibility of nutrients in calves fed $27 \% \mathrm{CP}, 17 \%$ fat milk replacers (MR) at different rates and weaned on different days as determined on d 53 to 56 (DM basis) in trial 2

\begin{tabular}{|c|c|c|c|c|}
\hline Item & $\begin{array}{c}\text { Program A: } 28-d \\
\text { wean, } 0.66 \mathrm{~kg} / \mathrm{d}\end{array}$ & $\begin{array}{l}\text { Program B: 42-d } \\
\text { wean, } 0.66 \mathrm{~kg} / \mathrm{d}\end{array}$ & $\begin{array}{l}\text { Program C: } 42-d \\
\text { wean, } 1.09 \mathrm{~kg} / \mathrm{d}\end{array}$ & SEM \\
\hline \multicolumn{5}{|l|}{ Intake, g/d } \\
\hline Starter $\mathrm{DM}^{1,2}$ & 2,321 & 2,053 & 1,804 & 86.0 \\
\hline MR DM & - & - & - & - \\
\hline Total $\mathrm{DM}^{1,2}$ & 2,321 & 2,053 & 1,804 & 86.0 \\
\hline $\mathrm{OM}^{1,2}$ & 2,133 & 1,887 & 1,658 & 82.4 \\
\hline $\mathrm{CP}^{1,2}$ & 466 & 413 & 363 & 19.2 \\
\hline $\mathrm{Fat}^{1,2}$ & 89 & 79 & 69 & 12.3 \\
\hline Calcium $^{1,2}$ & 20.1 & 17.8 & 15.6 & 0.77 \\
\hline Phosphorus ${ }^{1,2}$ & 12.5 & 11.1 & 9.7 & 0.56 \\
\hline \multicolumn{5}{|c|}{ Digestibility, $\mathrm{g} / \mathrm{g}$ of intake } \\
\hline $\mathrm{DM}^{2}$ & 0.823 & 0.820 & 0.767 & 0.0208 \\
\hline $\mathrm{OM}^{2}$ & 0.829 & 0.829 & 0.778 & 0.0204 \\
\hline $\mathrm{CP}$ & 0.789 & 0.760 & 0.743 & 0.0456 \\
\hline Fat & 0.883 & 0.900 & 0.860 & 0.0404 \\
\hline Calcium $^{2}$ & 0.556 & 0.546 & 0.422 & 0.0428 \\
\hline Phosphorus $^{2}$ & 0.670 & 0.675 & 0.484 & 0.0437 \\
\hline \multicolumn{5}{|l|}{ Digested, g/d } \\
\hline $\mathrm{DM}^{1,2}$ & 1,910 & 1,684 & 1,385 & 85.4 \\
\hline $\mathrm{OM}^{1,2}$ & 1,769 & 1,564 & 1,291 & 81.2 \\
\hline $\mathrm{CP}^{1,2}$ & 368 & 314 & 269 & 19.0 \\
\hline Fat $^{1,2}$ & 79 & 71 & 60 & 3.9 \\
\hline Calcium & 11.2 & 9.7 & 8.5 & 1.08 \\
\hline Phosphorus & 8.4 & 7.5 & 6.3 & 0.92 \\
\hline
\end{tabular}

${ }^{1}$ Programs A vs. B were different $(P<0.05)$ based on contrast statement.

${ }^{2}$ Programs B vs. $\mathrm{C}$ were different $(P<0.05)$ based on contrast statement.

bone growth (alkaline phosphatase), or dietary protein and energy balance (total protein, urea-N, glucose). No differences among treatments in either trial were detected in creatinine, albumin, alkaline phosphatase, total protein, and glucose. Urea-N was greater in calves fed program D during d 53 to 56 in trial 1 when all calves were weaned. This can likely be attributed to the higher CP starter (25.3 vs. $20.9 \% \mathrm{CP}$ ) fed to calves on program D compared with the other programs. Urea-N was greater in calves fed program $\mathrm{C}$ on $\mathrm{d} 21$ (preweaning) compared with calves fed less MR (1.09 vs. $0.66 \mathrm{~kg}$ of $\mathrm{DM} / \mathrm{d}$ ) on programs $\mathrm{A}$ and $\mathrm{B}$ and could be the result of greater CP intake.

Sabb et al. (1986) reported that pancreatic lipase activity in rats declined approximately $40 \%$ when dietary fat concentration was reduced from 23 to $17 \%$ of the diet (replaced by corn starch), and this decline was greater if the fat was saturated versus unsaturated. In rats, amylase activity was directly related to carbohydrate intake (Thornburg et al., 1987; Sankaran et al., 1992) and declined with the intake of fat (Forman and Schneeman, 1980). In calves, amylase was least in the milk-fed calf and increased as starter consumption increased during weaning and postweaning (Guilloteau et al., 1985). As dietary fat concentration increased, intake decreased in rats, but rats fed diets with butter consumed approximately $15 \%$ more feed at an equal fat concentration compared with rats fed diets with other sources of fat (Sabb et al., 1986). Therefore, in calves fed a somewhat constant amount of MR high in saturated fat with increasing consumption of starter with age, their total dietary concentration of fat declines with age. The digestive enzyme system of the neonatal calf does not appear to be as well defined as that of the rat but if the systems of the 2 species are somewhat similar, the change from a high saturated fat to a low fat diet and from a low starch to a high starch diet could lend itself to inefficiencies of digestion. Recently, it was reported that ADG was less in calves fed high fat MR $(20,23$, and $27 \%$ fat in the MR powder) than in calves fed MR with $17 \%$ fat, and differences in starter intake did not explain the difference in ADG (Hill et al., 2009a,b). Digestion of OM, DM, fat, Ca, and $\mathrm{P}$ decreasing as fat concentration increased from 13 to $23 \%$ of a $27 \% \mathrm{CP}$ MR powder fed at $0.66 \mathrm{~kg}$ of $\mathrm{DM} / \mathrm{d}$ explained much of the differences in ADG (Hill et al., 2009b). Calves weaned on d 28 in trial 2 (program A) had greater d-56 serum amylase concentrations, and calves fed the large amounts of MR in both trials 1 (program D) and 2 (program C) had lower serum amylase concentrations. Thus, early weaned calves would have less time spent on diets intermediate in fat and starch and may more quickly develop their amylase enzyme system.

\section{CONCLUSIONS}

Calves fed increasing amounts of a 27 to $29 \% \mathrm{MR}$ (up to $1.09 \mathrm{~kg} \mathrm{DM} / \mathrm{d}$ ) and weaned at 42 or $49 \mathrm{~d}$ in 
Table 10. Serum constituents in calves fed $27 \%$ CP, $17 \%$ fat milk replacer at different rates and weaned on different days in trial 2

\begin{tabular}{|c|c|c|c|c|}
\hline Item & $\begin{array}{l}\text { Program A: } 28-d \\
\text { wean, } 0.66 \mathrm{~kg} / \mathrm{d}\end{array}$ & $\begin{array}{l}\text { Program B: 42-d } \\
\text { wean, } 0.66 \mathrm{~kg} / \mathrm{d}\end{array}$ & $\begin{array}{c}\text { Program C: } 42-d \\
\text { wean, } 1.09 \mathrm{~kg} / \mathrm{d}\end{array}$ & SEM \\
\hline \multicolumn{5}{|c|}{ Alkaline phosphatase, units/L } \\
\hline d 21 & 129 & 136 & 149 & 14.7 \\
\hline d 35 & 135 & 145 & 155 & 14.1 \\
\hline d 56 & 159 & 154 & 143 & 12.8 \\
\hline \multicolumn{5}{|c|}{ Amylase, units/L } \\
\hline $\mathrm{d} 21^{2}$ & 58 & 56 & 39 & 5.7 \\
\hline d $35^{2}$ & 76 & 69 & 57 & 5.4 \\
\hline d $56^{1,2}$ & 93 & 81 & 68 & 5.2 \\
\hline \multicolumn{5}{|c|}{ Total protein, g/L } \\
\hline d 21 & 59.3 & 59.6 & 60.2 & 3.65 \\
\hline d 35 & 59.8 & 59.4 & 59.1 & 3.53 \\
\hline d 56 & 59.8 & 59.1 & 59.7 & 3.37 \\
\hline \multicolumn{5}{|c|}{ Albumin, g/L } \\
\hline d 21 & 18.3 & 18.7 & 18.6 & 1.41 \\
\hline d 35 & 18.6 & 18.9 & 18.3 & 1.29 \\
\hline d 56 & 18.1 & 18.2 & 18.8 & 0.87 \\
\hline \multicolumn{5}{|c|}{ Urea nitrogen, mmol/L } \\
\hline $\mathrm{d} 21^{2}$ & 3.6 & 3.5 & 4.2 & 0.26 \\
\hline d 35 & 3.4 & 3.5 & 3.7 & 0.29 \\
\hline d 56 & 3.2 & 3.3 & 3.0 & 0.24 \\
\hline \multicolumn{5}{|c|}{ Creatinine, umol/L } \\
\hline d 21 & 65 & 69 & 84 & 7.8 \\
\hline d 35 & 67 & 65 & 71 & 7.4 \\
\hline d 56 & 76 & 74 & 73 & 7.3 \\
\hline \multicolumn{5}{|c|}{ Glucose, $\mathrm{mmol} / \mathrm{L}$} \\
\hline d 21 & 5.4 & 5.4 & 5.8 & 0.21 \\
\hline d 35 & 5.3 & 5.3 & 5.3 & 0.19 \\
\hline d 56 & 5.3 & 5.3 & 5.2 & 0.18 \\
\hline
\end{tabular}

${ }^{1}$ Programs A vs. B were different $(P<0.05)$ based on contrast statement.

${ }^{2}$ Programs B vs. $\mathrm{C}$ were different $(P<0.05)$ based on contrast statement.

2 trials had low starter intakes, low concentrations of serum amylase, and low digestion of starter postweaning compared with calves fed a $21 \% \mathrm{CP}, 21 \%$ fat MR powder fed at $0.44 \mathrm{~kg} \mathrm{DM} / \mathrm{d}$. Although calves fed 1.09 $\mathrm{kg}$ of $\mathrm{DM} / \mathrm{d}$ had the greatest ADG for 0 to $56 \mathrm{~d}$, their lower starter intake and reduced digestion postweaning reduced their postweaning ADG. Calves fed $0.66 \mathrm{~kg}$ of $\mathrm{DM} / \mathrm{d}$ of a $27 \% \mathrm{CP}, 17 \%$ fat MR powder and weaned at 28 or $42 \mathrm{~d}$ had no reduction in starter intake or digestion compared with calves fed the conventional MR, and gained as much or more total BW from 0 to $84 \mathrm{~d}$ as calves fed $1.09 \mathrm{~kg}$ of DM/d. Calves fed $0.66 \mathrm{~kg}$ of DM/d of a $27 \% \mathrm{CP}, 17 \%$ fat MR and weaned at $28 \mathrm{~d}$ had the greatest intake of starter and greatest concentrations of serum amylase. Calves fed a 21\% CP, $21 \%$ fat MR powder at $0.44 \mathrm{~kg}$ of $\mathrm{DM} / \mathrm{d}$ had the least $\mathrm{ADG}$.

\section{REFERENCES}

AOAC. 2000. Official Methods of Analysis. Vol. I. 17th ed. Association of Official Analytical Chemists, Arlington, VA.

Bar-Peled, U., B. Robinzon, E. Maltz, H. Tagari, Y. Folman, I. Bruckental, H. Voet, H. Gacitua, and A. R. Lehrer. 1997. Increased weight gain and effects on production parameters of Holstein heifer calves that were allowed to suckle from birth to six weeks of age. J. Dairy Sci. 80:2523-2528.
Bouchard, R., G. J. Brisson, and J. P. Julien. 1973. Nutritive value of bacterial sludge and whey powders for protein in calf milk replacers and on chromic oxide as indicator of digestibility. J. Dairy Sci. 56:1445-1449.

Cowles, K. E., R. A. White, N. L. Whitehouse, and P. S. Erickson. 2006. Growth characteristics of calves fed an intensified milk replacer regimen with additional lactoferrin. J. Dairy Sci. 89:4835-4845.

Diaz, M. C., M. E. Van Amburg, J. M. Smith, J. M. Kelsey, and E. L. Hutten. 2001. Composition of growth of Holstein calves fed milk replacer from birth to 105-kilogram body weight. J. Dairy Sci. 84:830-842.

FASS. 1999. Guide for the Care and Use of Agricultural Animals in Agricultural Research and Teaching. 1st rev. ed. Federation of Animal Science Societies, Savoy, IL.

Forman, L. P., and B. O. Schneeman. 1980. Effects of dietary pectin and fat on the small intestinal contents and exocrine pancreas of rats. J. Nutr. 110:1992-1999.

Guilloteau, R., T. Corring, R. Toullec, and R. Guilhermet. 1985. Enzyme potentialities of the abomasums and pancreas of the calf. II. Effects of weaning and feeding a liquid supplement to ruminant animals. Reprod. Nutr. Dev. 25:481-493.

Hill, T. M., J. M. Aldrich, R. L. Schlotterbeck, and H. G. Bateman II. 2006a. Effects of feeding calves different rates and protein concentrations of twenty percent fat milk replacers on growth during the neonatal period. Prof. Anim. Sci. 22:252-260.

Hill, T. M., J. M. Aldrich, R. L. Schlotterbeck, and H. G. Bateman II. 2006b. Effects of feeding rate and concentrations of protein and fat of milk replacers fed to neonatal calves. Prof. Anim. Sci. $22: 374-381$

Hill, T. M., J. M. Aldrich, R. L. Schlotterbeck, and H. G. Bateman II. 2007a. Amino acids, fatty acids, and fat sources for calf milk replacers. Prof. Anim. Sci. 23:401-408. 
Hill, T. M., J. M. Aldrich, R. L. Schlotterbeck, and H. G. Bateman II. 2007b. Effects of the feeding rate of high protein calf milk replacers. Prof. Anim. Sci. 23:649-655.

Hill, T. M., H. G. Bateman II, J. M. Aldrich, and R. L. Schlotterbeck 2009a. Effect of consistency of nutrient intake from milk and milk replacer on dairy calf performance. Prof. Anim. Sci. 25:85-92.

Hill, T. M., H. G. Bateman II, J. M. Aldrich, and R. L. Schlotterbeck. 2009b. Effects of fat concentration of a high protein milk replacer on calf performance. J. Dairy Sci. 92:5147-5153.

Hill, T. M., H. G. Bateman II, J. M. Aldrich, R. L. Schlotterbeck, and K. G. Tanan. 2008a. Optimal concentrations of lysine, methionine, and threonine in milk replacers for calves less than five weeks of age. J. Dairy Sci. 91:2433-2442.

Jahn, E., and P. T. Chandler. 1976. Performance and nutrient requirements of calves fed varying percentages of protein and fiber. J. Anim. Sci. 42:724-735.

Jasper, J., and D. M. Weary. 2002. Effects of ad libitum milk intake on dairy calves. J. Dairy Sci. 85:3054-3058.

Kehoe, S. I., C. D. Dechow, and A. J. Heinrichs. 2007. Effects of weaning age and milk feeding frequency on dairy calf growth, health and rumen parameters. Livest. Sci. 110:267-272.

Khan, M. A., H. J. Lee, W. S. Lee, H. S. Kim, K. S. Ki, T. Y. Hur, G. H. Suh, S. J. Kang, and Y. J. Choi. 2007a. Structural growth, rumen development, and metabolic and immune responses of Holstein male calves fed milk through step-down and conventional methods. J. Dairy Sci. 90:3376-3387.

Khan, M. A., H. J. Lee, W. S. Lee, H. S. Kim, S. B. Kim, K. S. Ki, J. K. Ha, H. G. Lee, and Y. J. Choi. 2007b. Pre- and postweaning performance of Holstein female calves fed milk through step-down and conventional methods. J. Dairy Sci. 90:876-885.

NRC. 2001. Nutrient Requirements of Dairy Cattle. 7th rev. ed. Natl. Acad. Sci., Washington, DC.
Owen, F. G., and L. L. Larson. 1982. A simplified liquid feeding program for calves. J. Dairy Sci. 65:1350-1356.

Sabb, J. E., P. M. Gadfrey, and P. M. Brannon. 1986. Adaptive response to rat pancreatic lipase to dietary fat: Effects of amount and type of fat. J. Nutr. 116:892-899.

Sankaran, H., C. W. Deveney, E. C. Larkin, and G. A. Rao. 1992 Carhoydrate intake determines pancreatic acinar amylase activity and release despite chronic alcoholemia in rats. J. Nutr. 122:18841891

Strzetelski, J., B. Niwinska, J. Kowalezyk, and A. Jurkiewiez. 2001. Effect of milk repalcer feeding frequency and level of concentrate intake and rearing performance of calves. J. Anim. Feed Sci. 10:413-420.

Terre, M., M. Devant, and A. Bach. 2006. Performance and nitrogen metabolism of calves fed conventionally or following an enhancedgrowth feeding program during the preweaning period. Livest. Sci. 105:109-119.

Terre, M., M. Devant, and A. Bach. 2007. Effect of level of milk replacer fed to Holstein calves on performance during the preweaning period and starter digestibility at weaning. Livest. Sci. 110:82-88.

Thornburg, W., J. Grimes, T. Goda, S. Bustamante, P. Pollack, and O. Koldovsky. 1987. Response of activity of jejunal disaccharides and pancreatic amylase in young and middle aged rats to a high carbohydrate diet. J. Nutr. 117:63-69.

Warner, R. G., W. P. Flatt, and J. K. Loosli. 1956. Dietary factors influencing the development of the animal's stomach. J. Agric. Food Chem. 4:788-792.

Wildman, E. E., G. M. Jones, P. E. Wagner, R. L. Boman, H. F. Trout Jr., and T. N. Lesch. 1982. A dairy cow body condition scoring system and its relationship to selected production characteristics. J. Dairy Sci. 65:495-501 